Jurnal Inkofar * Volume 1 No. 2 Desember 2019 * ISSN: 2615-3645 (Print) / 2581-2920 (Online)

Tersedia secara online di: http://www.politeknikmeta.ac.id/meta/ojs/

\title{
UJI AKTIVITAS ANTIOKSIDAN GABUNGAN EKSTRAK ETANOL KULIT PETAI DAN BIJI PETAI (Parkia speciosa Hassk.) DENGAN METODE DPPH
}

\author{
Ekadipta $^{1}$, Febri Hidayat ${ }^{2}$, Okta Asri Naimah ${ }^{3}$ \\ 1Program Studi Farmasi/ Fakultas Sains dan Teknologi/ Institut Sains dan Teknologi Al- \\ Kamal/ekadipta@gmail.com \\ 2Program Studi Farmasi/ Fakultas Sains dan Teknologi/Institut Sains dan Teknologi Al- \\ Kamal/ hidayat2368@gmail.com \\ 3Program Studi Farmasi/ Fakultas Sains dan Teknologi/ Institut Sains dan Teknologi Al- \\ Kamal/ Oktaasrinaimah@gmail.com
}

\begin{abstract}
Petai plant (Parkia speciosa Hassk.) has potential as a natural antioxidant. The purpose of this research is to know the antioxidant activity from the combination of ethanol extract of petai skin and petai seeds. Extration proces was done in a maceration with $70 \%$ ethanolum, then extract was identified the chemical subtances. Evaluation of the antioxidant activity was done with DPPH methode using Vitamin $C$ as standard. Antioxidant ability was measured using spektrofotometer UVVisible at $517 \mathrm{~nm}$ based on DPPH absorbance reduction after extraxt addition. Identification of ethanol extract seeds petai in chemical substances show there are flavonoid, alkaloid, trepenoid, tannin, glikosid, fenol.. The result of antioxidant activity evaluation show that $I C_{50}$ of skin petai is $10,413 \mu \mathrm{g} / \mathrm{ml}$ and result of antioxidant activity evaluation show that $I_{50}$ of seeds petai is 339,741 $\mu \mathrm{g} / \mathrm{ml}$. Combine result antioxidant activity ethanol ekstract skin petai and seeds petai is $27,254 \mu \mathrm{g} / \mathrm{ml}$. while Vitamin $C$ have $I C_{50} 6,37 \mu \mathrm{g} / \mathrm{ml}$. The conclusion is antioxidant activity combine ethanol extract skin and seeds petai at very strong level.
\end{abstract}

Keywords: Petai Skin,petai seeds, Antioxidant activity, Combine Antioxidan, DPPH Methode

\begin{abstract}
ABSTRAK
Tanaman petai (Parkia speciosa Hassk.) memiliki potensi sebagai antioksidan alami. Tujuan penelitian ini untuk mengetahui aktivitas antioksidan dari gabungan ekstrak etanol kulit petai dan biji petai. Ekstraksi dilakukan dengan cara maserasi dengan pelarut etanol $70 \%$, kemudian ekstrak dilakukan identifikasi golongan senyawa kimia. Pengujian aktivitas antioksidan dilakukan dengan menggunakan metode DPPH dengan senyawa pembanding vitamin C. Kemampuan antioksidan diukur berdasarkan penurunan absorbansi DPPH pada panjang gelombang $517 \mathrm{~nm}$ setelah penambahan ekstrak dengan menggunakan spektrofotometri UV-Visible. Identifikasi golongan senyawa kimia pada ekstrak etanol biji petai mengandung flavonoid,alkaloid, trepenoid, tannin, glikosid, fenol. Hasil uji aktivitas antioksidan ekstrak etanol kulit petai memiliki $\mathrm{IC}_{50} \quad 10,413 \mu \mathrm{g} / \mathrm{ml}$ dan hasil uji aktivitas antioksidan ekstrak etanol biji petai memiliki $\mathrm{IC}_{50} 339,741 \mu \mathrm{g} / \mathrm{ml}$. Gabungan uji aktivitas antioksidan ekstrak etanol kulit petai dan biji petai adalah sebesar 27,254 $\mu \mathrm{g} / \mathrm{ml}$. Sedangkan Vitamin $\mathrm{C}$ memiliki $\mathrm{IC}_{50} 6,37 \mu \mathrm{g} / \mathrm{ml}$. Kesimpulannya gabungan ekstrak etanol kulit dan biji petai memiliki aktivitas antioksidan sangat kuat.
\end{abstract}

Kata Kunci: Kulit petai, Biji Petai, Aktivitas Antioksidan, Antioksidan Gabungan, Metode DPPH

\section{PENDAHULUAN}

\subsection{Latar Belakang}

Indonesia merupakan negara tropis yang memiliki ekosistem berupa flora dan fauna yang tergolong cukup beragam di dunia. Kekayaan alam yang cukup berpotensi di Indonesia adalah adanya berbagai spesies flora, dari 40 ribu jenis flora yang tumbuh di dunia, 30 ribu diantaranya tumbuh di Indonesia. Sekitar 26\% telah dibudidayakan, sedangkan sisanya masih tumbuh liar di hutan. Lebih dari 940 jenis tanaman yang dibudidayakan (Syukur dan Hernani, 2001). Kekayaan flora di Indonesia salah satunya kekayaan tumbuhan, yang dapat dijadikan sebagai tanaman obat. Masyarakat menggunakan tanaman obat tersebut sebagai salah satu alternatif pengobatan, baik untuk pencegahan (preventif), 
penyembuhan (kuratif), pemulihan kesehatan (rehabilitatif) maupun peningkatan kesehatan (promotif) (Katno dan S. Pramono, 2002).

Salah satu tanaman di Indonesia yang berpotensi sebagai tanaman obat adalah tanaman petai (Parkia speciosa Hassk.). Petai, merupakan pohon tahunan topikal dari suku polong-polongan, anak suku petai-petaian. Tumbuhan ini tersebar luas di Nusantara bagian barat. Bijinya, yang disebut "petai" juga dikonsumsi ketika masih muda, baik segar maupun direbus. Kulit petai diketahui memilki manfaat sebagai antioksidan, antidiabetik, dan antiangiogenik (Susilo, 2012). Hal ini karena di dalamnya mengandung senyawa fenol dan flavonoid (Karim A, 2012).

Dalam beberapa tahun ini, upaya mengatasi pembentukan radikal bebas dengan produk farmasi dan bahan pangan diatasi oleh antioksidan dari bahan alami (Campanella L et all, 2006). Beberapa laporan juga menyebutkan bahwa senyawa antioksidan dapat menetralkan radikal bebas dan selanjutnya dapat menghalangi terjadinya mutasi sel (Ghaskadbi et all, 1992). Secara umum tumbuhan merupakan sumber senyawa antioksidan seperti fenol, flavonoid, curcuminoid dan asam-asam organik yang tersebar pada berbagai bagian tumbuhan seperti akar, batang, kulit, daun, buah, dan biji serta bagian bunga. Antioksidan merupakan senyawa yang dapat menghambat reaksi oksidasi dengan mengikat radikal bebas dan molekul yang sangat reaktif sehingga kerusakan sel dapat dihambat.

Radikal bebas berlebih dapat menyebabkan stres oksidatif. Stres oksidatif disebabkan oleh produksi Reactive oxygen species (ROS) yang berlebihdan dapat menjadi perantara penting kerusakan struktur sel, termasuk lipid dan membran, protein dan DNA. Akibatnya stress oksidatif dapat memicu berbagai penyakit dan mempercepat penuaan (Sen et all, 2010).

Berdasarkan uraian diatas maka dilakukan penelitian meliputi karakteristik simplisia, skrining fitokimia serta uji aktivitas antioksidan gabungan ekstrak biji petai dan kulit petai (Parkia speciosa Hassk.) menggunakan metode DPPH.

\section{METODE PENELITIAN}

\subsection{Jenis Penelitian}

Penelitian ini bersifat eksperimental dan bertujuan untuk membuktikan aktivitas antioksidan gabungan ekstrak kulit petai dan biji petai (Parkia Speciosa Hassk.) menggunakan metode DPPH.

\subsection{Bahan dan Alat}

Bahan-bahan yang digunakan dalam penelitian ini: Kulit petai, biji petai, etanol $70 \%$, methanol, $\mathrm{H}_{2} \mathrm{SO}_{4}, \mathrm{CH}_{3} \mathrm{COOH}, \mathrm{HCl}$, Akuades, Pereaksi Bouchardat, Pereaksi Mayer, $\mathrm{FeCl}_{3}$, DPPH (1,1- difenil2 pikrilhidrazil), DMSO.

Alat yang digunakan pada penelitian ini adalah Timbangan analitik, wadah maserator, kertas saring, alat-alat gelas, botol kaca, alumunium foil, Rotari evaporator, Spektrofotometri Uv- Vis.

\subsection{Pengamatan Organoleptis}

Uji Organoleptik atau uji indera atau uji sensori sendiri merupakan cara pengujian dengan menggunakan indera manusia sebagai alat utama untuk pengukuran daya penerimaan terhadap produk (Soekarto, 1981). Dilakukan dengan mengamati perubahan-perubahan bentuk, bau dan warna ekstrak yang dilakukan secara visual.

\subsection{Pemeriksaan Skrining Fitokimia}

a. Pemeriksaan triterpenoid

Sebanyak $1 \mathrm{~g}$ sampel dimaserasi dengan $20 \mathrm{ml}$ eter selama 2 jam, lalu disaring. Filtrat diuapkan dalam cawan penguap. Pada sisa dalam cawan penguap ditambahkan 2 tetes asam asetat anhidrid dan 1 tetes asam sulfat pekat. Timbul warna ungu atau merah kemudian berubah menjadi hijau biru menunjukkan adanya steroida triterpenoida (Voigt, 1995).

\section{b. Pemeriksaan alkaloida}

Sebanyak 500mg zat uji dimasukkan kedalam tabung reaksi kemudian tambahkan $1 \mathrm{ml}$ HCL $2 \mathrm{~N}$ dan $9 \mathrm{ml}$ aquades, dipanaskan diatas penangas air setelah itu didinginkan kemudian ditambah 2 tetes pereaksi bouchardat. Zat uji positif mengandung alkaloid jika terbentuk endapan merah. Apabila diberi pereaksi mayer ada endapan berwarna putih menunjukkan adanya alkaloid (Sastrohamidjojo, 2001).

c. Pemeriksaan glikosida

Ekstrak ditimbang sebanyak 500 g kemudian disari dengan $30 \mathrm{ml}$ campuran 7 bagian volume etanol $96 \%$ dan 3 bagian volume air suling, selanjutnya ditambahkan $10 \mathrm{ml} \mathrm{HCl} 2 \mathrm{~N}$, direfluks selama 10 menit, didinginkandan disaring. Pada $30 \mathrm{ml}$ filtrat ditambahkan $25 \mathrm{ml}$ air suling dan $25 \mathrm{ml}$ timbal (II) 
asetat 0,4 M, dikocok, didiamkan selama 5 menit lalu disaring. Filtrat disaring sebanyak 3 kali, tiap kali dengan $20 \mathrm{ml}$ campuran 3 bagian volume kloroform dan 2 bagian volume isopropanol. Diambil lapisan air kemudian ditambahkan $2 \mathrm{ml}$ air dan 5 tetes pereaksi Molisch, ditambahkan hati-hati $2 \mathrm{ml}$ asam sulfat pekat terbentuk cincin warna ungu pada batas kedua cairan menunjukkan adanya ikatan gula (Saifudin A dkk, 2011).

d. Pemeriksaan flavonoida

Sebanyak 0,5 gram ekstrak kental dilarutkan dalam 1-2 ml etanol (95\%), kemudian ditambahkan 0,5 gram serbuk seng P dan $2 \mathrm{ml}$ HCL $2 \mathrm{~N}$ dan didiamkan selama 1 menit. Kemudian ditambahkan 10 tetes HCL pekat $\mathrm{P}$, jika dalam waktu 2 sampai 5 menit terjadi warna merah intensif, menunjukkan adanya flavonoid (Saifudin A dkk, 2011).

e. Pemeriksaan tannin

Sebanyak $0,5 \mathrm{~g}$ sampel disari dengan $10 \mathrm{ml}$ air suling, disaring lalu filtratnya diencerkan dengan air suling sampai tidak berwarna. Diambil $2 \mathrm{ml}$ larutan lalu ditambahkan 1 sampai 2 tetes pereaksi besi (III) klorida. Terjadi warna biru atau hijau kehitaman menunjukkan adanya tanin (Voigt, 1995).

f. Pemeriksaan saponin

Sebanyak 0,5 g sampel dimasukkan ke dalam tabung reaksi dan ditambahkan $10 \mathrm{ml}$ air suling panas, didinginkan kemudian dikocok kuat-kuat selama 10 detik, timbul busa yang mantap tidak kurang dari 10 menit setinggi $1-10 \mathrm{~cm}$. Ditambahkan 1 tetes larutan asam klorida $2 \mathrm{~N}$, bila buih tidak hilang menunjukkan adanya saponin (Saifudin A dkk, 2011).

g. Pemeriksaan fenol

Ekstrak kental yang telah diencerkan dengan methanol ditambahkan dengan larutan $\mathrm{FeCl}_{3}$ lalu diamati perubahan warna. Jika terbentuk warna ungu tua menunjukan adanya fenol (Voigt, 1995).

\subsection{Pembuatan Larutan DPPH}

Sejumlah $5 \mathrm{mg}$ DPPH ditimbang dan dilarutkan dalam $100 \mathrm{ml}$ etanol p.a didapatkan konsentrasi DPPH $125 \mu \mathrm{g} / \mathrm{ml}$.

\subsection{Pembuatan Larutan Ekstrak}

Pembuatan larutan induk (konsentrasi $1000 \mu \mathrm{g} / \mathrm{ml}$ ) Sejumlah $10 \mathrm{mg}$ dari masing-masing ekstrak kulit petai dan biji petai ditimbang dan dilarutkan dengan DMSO sebanyak $1 \mathrm{ml}$, disonikasi hingga larut, kemudian divorteks.

\subsection{Pembuatan Larutan Vitamin $C$ sebagai pembanding}

Ditimbang $10 \mathrm{mg}$ vitamin $\mathrm{C}$ dan dilarutkan dalam $1 \mathrm{ml}$ DMSO hingga homogen.

\subsection{Penentuan Panjang Gelombang Maksimum DPPH}

Larutan DPPH yang telah dibuat ditentukan spektrum serapannya menggunakan spektrofotometer UV-Vis pada panjang gelombang $400 \mathrm{~nm}$ hingga $800 \mathrm{~nm}$, ditentukan panjang gelombang optimumnya.

\subsection{Pengujian Aktivitas Antioksidan terhadap ekstrak dan Vitamin $\mathbf{C}$}

Pengujian Ekstrak kulit petai dan biji petai, Larutan uji dipipet $2 \mathrm{ml}$ dimasukkan ke dalam vial, ditambahkan $2 \mathrm{ml} \mathrm{DPPH}$, diinkubasi pada suhu $37^{\circ} \mathrm{C}$ selama 30 menit dan diukur serapannya pada panjang gelombang $517 \mathrm{~nm}$; Pengujian Antioksidan gabungan ekstrak kulit petai dan biji petai, masing-masing larutan uji, kulit petai dan biji petai dipipet $2 \mathrm{ml}$ dimasukkan dalam vial dan ditambahkan $4 \mathrm{ml} \mathrm{DPPH}$, diinkubasi suhu $37^{\circ} \mathrm{C}$ selama 30 menit dan diukur serapannya pada panjang gelombang $517 \mathrm{~nm}$; Pengujian Blanko, $2 \mathrm{ml}$ etanol p,a dipipet dan ditambahkan $2 \mathrm{ml}$ DPPH

\section{HASIL DAN PEMBAHASAN}

3.1. Pengamatan Organoleptik

Pengujian karakteristik ekstrak meliputi uji organoleptik yaitu bentuk, warna, dan bau. Penentuan organoleptik ini termasuk salah satu parameter spesifik yang ditentukan dengan menggunakan panca indera dan bertujuan untuk pengenalan awal secara sederhana dan bersifat subjektif. Karakteristik dari ekstrak kulit petai yang didapat berbentuk kental, kecoklatan dan berbai khas, sama halnya dengan karakteristik dari ekstrak biji petai yang didapat berbentuk kental, kecoklatan serta berbau khas.

Tabel 1. Hasil Pengamatan Uji Organoleptik Ekstrak

\begin{tabular}{cccc}
\hline No. & Karakteristik & Kulit Petai & Biji Petai \\
\hline 1 & Bentuk & Kental, Agak Lengket & Kental, Agak Lengket \\
2 & Warna & Coklat kehitaman & Coklat kehitaman \\
3 & Bau & Khas, menyengat & Khas, menyengat \\
\hline
\end{tabular}




\subsection{Hasil Pemeriksaan Skrining Fitokimia}

Skrining fitokimia merupakan metode analisis kualitatif yang bertujuan untuk mengetahui kandungan kimia yang terdapat dalam kulit petai dan biji petai. Metode ini dipilih karena metode ini sederhana dan cepat.

\begin{tabular}{cccc}
\multicolumn{4}{c}{ Tabel 2. Hasil Pemeriksaan Skrining Fitokimia } \\
\hline No. & Pengujian & Kulit Petai & Biji Petai \\
\hline 1 & Alkaloid & - & + \\
2 & Flavonoid & + & + \\
3 & Saponin & + & + \\
4 & Trepenoid & + & + \\
5 & Tanin & + & - \\
6 & Glikosida & + & + \\
7 & Fenol & + & + \\
\hline Keterangan $:(+)=$ Terdeteksi, $(-)=$ Tidak terdeteksi
\end{tabular}

\section{1.}

\subsection{Pengujian Aktivitas Antioksidan}

Uji aktivitas antioksidan gabungan ekstrak kulit petai dan biji petai Parkia speciosa Hassk. dilakukan dengan menggunakan metode penangkapan radikal bebas DPPH (2,2-Difenil-1-Pikrilhidrazil). Metode DPPH dipilih karena memerlukan sedikit sampel, sederhana, mudah, cepat, dan peka untuk mengevaluasi aktivitas antioksidan dari senyawa bahan alam. Pada metode ini, DPPH bertindak sebagai model radikal bebas yang akan berikatan dengan senyawa antioksidan. Dimana senyawa pembanding yang digunakan adalah vitamin C (Lailia, 2015).

Uji aktivitas antioksidan dilakukan dengan menggunakan spektrofotometer UV-Vis, pada panjang gelombang $517 \mathrm{~nm}$. Dari nilai absorbansi DPPH yang diperoleh dapat ditentukan nilai persentasi penghambatan radikal DPPH (\% inhibisi). Dari nilai \% inhibisi dapat ditentukan nilai IC $_{50}$ (Inhibitory Concentration). Nilai $\mathrm{IC}_{50}$ merupakan bilangan yang menunjukkan besarnya konsentrasi ekstrak (ppm) yang mampu menghambat proses oksidasi sebesar 50\%. Semakin kecil nilai $\mathrm{IC}_{50}$ berarti semakin tinggi aktivitas antioksidan.

Tabel 3. Uji Aktivitas Antioksidan

\begin{tabular}{cccccc}
\hline No & Nama Sample & $\begin{array}{c}\text { Sangat Kuat }<\mathbf{5 0} \\
\boldsymbol{\mu g} / \mathbf{m L}\end{array}$ & $\begin{array}{c}\text { Kuat 50-100 } \\
\boldsymbol{\mu g} / \mathbf{m L}\end{array}$ & $\begin{array}{c}\text { Sedang 101- } \\
\mathbf{2 5 0} \boldsymbol{\mu g} / \mathbf{m L}\end{array}$ & $\begin{array}{c}\text { Lemah 250-500 } \\
\boldsymbol{\mu g} / \mathbf{m L}\end{array}$ \\
\hline 1 & Vitamin C & $6,376 \mu \mathrm{g} / \mathrm{mL}$ & - & - & - \\
2 & Ekstrak Etanol Kulit Petai & $10,413 \mu \mathrm{g} / \mathrm{mL}$ & - & - & - \\
3 & Ekstrak Etanol Biji Petai & - & - & - & $339,741 \mu \mathrm{g} / \mathrm{mL}$ \\
4 & Gabungan Ekstrak Etanol & $27,254 \mu \mathrm{g} / \mathrm{mL}$ & - & - \\
\hline
\end{tabular}

1.

\section{KESIMPULAN}

Ekstrak Kulit Petai mengandung enyawa Flavonoid, Saponin, Trepenoid, Tanin dan Fenol. Sedangkan Eksytak Biji Petai mengandung Alkaloid, Flavonoid, Saponin, Trepenoid, Fenol; Nilai IC50 Ekstrak Kulit Petai adalah $10.413 \mu \mathrm{g} / \mathrm{ml}$ dan Nilai IC50 Ekstrak Biji Petai $339.741 \mu \mathrm{g} / \mathrm{ml}$. Nilai IC50 Gabungan Ekstrak Kulit petai dan Biji Petai $27.2545 \mu \mathrm{g} / \mathrm{ml}$ Nilai IC50 Vitamin C sebagai pembanding adalah $6,3767 \mu \mathrm{g} / \mathrm{ml}$; Gabungan Antioksidan Ekstrak Kulit Petai dan Biji Petai saling menguatkan sehingga ekstrak gabungan Kulit Petai dan Biji Petai memiliki Aktivitas sebagai Antioksidan dengan Katagori Sangat Kuat.

\section{DAFTAR PUSTAKA}

Campanella L et all (2006) 'Antioxidant Capacity of Dry Extracts Checked By Voltammetric Method', J Food Agric Environ, 4, pp. 135-144.

Sen et all (2010) 'Free Radicals, Antioxidants, Diseases and Phytomedicines: Current Status and Future Prospect', International Journal of Pharmaceutical Sciences Review and Research, 3(1), pp. 91-100.

Ghaskadbi et all (1992) 'Modulation of Cyclophosphamide Mutagebicity by Vitamin C In Vivo Rodent Micronucleus Assay', Teratogenesis, Carcinog. Mutagen, 12, pp. 11-13.

Karim A, A. A. (2012) Review: Fruit Pod Extracts as a Source of Nutraceuticals and Pharmaceuticals. Available at: www.mdpi.com/journal/molecules. 
Jurnal Inkofar * Volume 1 No. 2 Desember 2019 * ISSN: 2615-3645 (Print) / 2581-2920 (Online)

Tersedia secara online di: http://www.politeknikmeta.ac.id/meta/ojs/

Katno dan S. Pramono (2002) Tingkat Manfaat Dan Keamanan Tanaman Obat Dan Obat Tradisional. Universitas Gajah Mada.

Lailia, F. (2015) Uji Aktivitas Antioksidan Ekstrak Buah Mentega (Diospyros discolor Willd.) Dengan Metode DPPH. Akademi Farmasi Hang Tuah.

Saifudin A dkk (2011) Standarisasi Bahan Obat Alam. Yogyakarta: Graha Ilmu.

Sastrohamidjojo, H. (2001) Spektroskopi. Yogyakarta: Liberty Press.

Soekarto (1981) Penilaian Organoleptis. Bogor: Pusbangtepa Institut Pertanian Bogor.

Susilo, J. (2012) Budidaya Petai Prospek Pasar Terbuka. Yogyakarta: Penerbit Pustaka Baru Press.

Syukur dan Hernani (2001) Budi Daya Tanaman Obat Komersia. Jakarta: Penebar Swadaya.

Voigt, R. (1995) Buku Pelajaran Teknologi Farmasi. Yogyakarta: UGM Press. 